Stirling Management School

\title{
Life Satisfaction and Air Quality in Europe
}

Susana Ferreira

Alpaslan Akay

Finbarr Brereton

Juncal Cuñado

Peter Martinsson

Mirko Moro

Tine F. Ningal

Stirling Economics Discussion Paper 2013-02

February 2013

Online at

http://www.management.stir.ac.uk/research/economics/workingpapers 


\title{
Life Satisfaction and Air Quality in Europe
}

\author{
Susana Ferreira, University of Georgia, USA \\ sferreir@uga.edu \\ Alpaslan Akay, IZA, Germany \\ akay@iza.org \\ Finbarr Brereton, University College Dublin, Ireland \\ finbarr.brereton@ucd.ie \\ Juncal Cuñado, Universidad de Navarra, Spain \\ jcunado@unav.es \\ Peter Martinsson, University of Gothenburg, Sweden \\ Peter.Martinsson@economics.gu.se
}

Mirko Moro, University of Stirling, The United Kingdom

mirko.moro@stir.ac.uk

Tine F. Ningal, University College Dublin, Ireland

tine.ningal@ucd.ie

\begin{abstract}
Concerns for environmental quality and its impact on people's welfare are fundamental arguments for the adoption of environmental legislation in most countries. In this paper, we analyse the relationship between air quality and subjective well-being in Europe. We use a unique dataset that merges three waves of the European Social Survey with a new dataset on environmental quality including $\mathrm{SO}_{2}$ concentrations and climate in Europe at the regional level. We find a robust negative impact of $\mathrm{SO}_{2}$ concentrations on selfreported life satisfaction.
\end{abstract}

JEL classification: I31, Q51, Q53, Q54

Key words: Air Quality; $\mathrm{SO}_{2}$ Concentrations; Subjective Well-Being; Life Satisfaction; Europe; European Social Survey; GIS 


\section{Introduction}

Concerns for environmental quality and its impact on people's welfare date back, at least, to the industrial revolution. However, conventional welfare measures, Gross Domestic Product (GDP) in particular, ignore many important non-market factors that may explain individual well-being, including environmental quality. In recent years, a broader perspective towards the measurement of welfare is emerging among economists (e.g., Deaton, 2008; Fleurbaey, 2009). Two manifestations of this broader perspective have been an increased interest in using people's subjective well-being as a proxy for utility, and hence a welfare indicator, and the consideration of a rich spectrum of factors (in addition to income) to explain people's well-being.

In economics, the interest in subjective well-being (often measured using "happiness" or "life satisfaction" questions) has increased rapidly over the last decade (for overviews see, e.g., Frey and Stutzer, 2002; Dolan et al., 2008; van Praag and Ferrer-i-Carbonell, 2008; MacKerron, 2011). ${ }^{1}$ This new line of research has shown that many factors beyond income significantly affect people's subjective well-being, including health, employment, and marital status. The effect of environmental quality on subjective well-being has also begun to be investigated (for a comprehensive summary see Welsch and Kühling, 2009; and Welsch, 2007; 2009). Research shows that several dimensions of environmental quality: noise (Van Praag and Baarsma, 2005), climate (e.g., Rehdanz and Maddison, 2005) and natural hazards (Luechinger and Raschky, 2009), have a significant influence on subjective well-being in the expected direction.

\footnotetext{
${ }^{1}$ Both happiness and life satisfaction are components of subjective well-being. Although slightly different constructs, economists often use them interchangeably to measure overall feelings of well-being. For a discussion on different question modes on subjective well-being and validity see, e.g., Kahneman and Krueger (2006).
} 
There are a number of papers analysing the relationship between air pollution and subjective well-being. A common challenge to these papers is that to obtain high quality data on air pollution with detailed spatial disaggregation and link these to a specific individual is almost an impossible task. Unlike for other individual characteristics that might influence people's subjective well-being, information on environmental characteristics is typically not collected in the survey instrument and thus cannot be matched with respondents at the household level. For example, Rehdanz and Maddison (2008), using German data find that the self-reported adverse impact of air pollution and subjective well-being are negatively correlated. However, they do not use actual pollution indicators.

A number of early papers use cross-section and panel data where measured air quality for several pollutants is collected at the country level e.g., Welsch 2002; 2006; 2007). The overall findings are that air quality has a significant impact on people's subjective well-being. More recently, Luechinger (2010) investigates the relationship between $\mathrm{SO}_{2}$ emissions at the country level and subjective well-being data in several European countries and finds a negative and robust relationship between the two variables.

Papers that use more spatially disaggregated pollution data have focused in one country. For example, Luechinger (2009) links $\mathrm{SO}_{2}$ concentrations from monitoring stations in Germany to subjective well-being using data for almost two decades. He finds a significant negative impact of $\mathrm{SO}_{2}$ pollution on well-being. Ferreira and Moro (2010) use regional data from Ireland with similar results for $\mathrm{PM}_{10}$. Smyth et al. (2008) use pollution data in 30 cities in urban China, and also find a clear negative impact of $\mathrm{SO}_{2}$ emission on subjective well-being. MacKerron and Mourato (2009) find that local 
nitrogen dioxide concentrations significantly reduce the life satisfaction of Londoners. Levinson (2012) uses an innovative approach by linking subjective well-being with air quality in the county or city where the respondent was surveyed at the day when the interview was conducted. He finds that higher levels of particulates are negatively correlated with well-being in the US.

Our study is the first multi-country analysis that uses spatially disaggregated data at the subnational level (regional data) on ambient air pollution concentrations $\left(\mathrm{SO}_{2}\right)$ coupled with other spatial controls (climate data on temperature and precipitation, and regional indicators of economic performance) to explain individual subjective wellbeing in Europe. We use survey data collected in the first three rounds of the European Social Survey (ESS) ${ }^{2}$ between 2002 and 2007 matched with a uniquely created dataset on sulfur dioxide $\left(\mathrm{SO}_{2}\right)$ concentrations at the regional level (248 regions) in Europe. We use Geographic Information Systems (GIS) to interpolate annual mean pollutant concentrations for $\mathrm{SO}_{2}$ from a network of monitoring stations in 23 European countries between 2002 and 2007, and match them (together with other spatial controls) with individual responses to the ESS during the same period.

A recent paper by Murray et al. (2011) considers the regional variation of climate across Europe and its impact on life satisfaction for the third wave of the European Values Survey. However, it does not consider air pollution, which, at least in the medium-run, is more amenable to policy intervention than climate.

Overall, our research feeds both into the recent development in subjective wellbeing research that considers environmental quality as a key determinant of subjective

\footnotetext{
2 For more information about the European Social Survey see Section 2 and www.europeansocialsurvey.org.
} 
well-being as well as into a more policy-oriented interest in subjective well-being research.

Dolan et al. (2011) argue that subjective well-being data can be used in a number of ways by policymakers, and they highlight three areas: (i) monitoring progress, (ii) informing policy design, and (iii) policy appraisal. However, using subjective wellbeing to inform policy-makers is nothing new. For a long time, Bhutan has used subjective well-being information to both evaluate and plan public policies, and uses Gross National Happiness (GNH) as a national indicator of progress in addition to GDP. Recently, French president Nicholas Sarkozy set up a commission ("Stiglitz Commission"), led by Nobel Prize laureates Joseph Stiglitz and Amartaya Sen to "identify the limits of GDP as an indicator of economic performance and social progress; [...] to consider what additional information might be required for the production of more relevant indicators of social progress; to assess the feasibility of alternative measurement tools, and to discuss how to present the statistical information in an appropriate way" (Stiglitz et al., 2009, p.3). ${ }^{3}$ Moreover, the United Kingdom under the leadership of Prime Minister David Cameron has established the "National Wellbeing Project," and the Office for National Statistics will publish the UK's first official subjective well-being index in 2012.

In this context, it is important to improve our understanding of the determinants of subjective well-being, in particular those that, like air quality, can be influenced, directly or indirectly, by public policy. The European Union (EU) has established an extensive body of environmental legislation over the decades to improve individual well-being by ensuring health-based standards for pollutants. For example, Directives 
1996/62/EC, 1999/30/EC and 2002/3/EC ${ }^{4}$ establish limit values for concentrations of sulphur dioxide $\left(\mathrm{SO}_{2}\right)$, oxides of nitrogen $\left(\mathrm{NO}\right.$ and $\left.\mathrm{NO}_{2}\right)$, particulate matter $\left(\mathrm{PM}_{10}\right)$, and carbon monoxide $(\mathrm{CO})$ in ambient air.

In this paper (as in Luechinger, 2009; 2010), we limit our analysis to $\mathrm{SO}_{2}$ for a number of reasons; firstly, it has an adverse impact on human health (e.g., Folinsbee, 1992), and, among the pollutants mentioned above, only $\mathrm{PM}_{10}$ and $\mathrm{SO}_{2}$ can be directly noticed by humans. We note, however, that it is not necessary that respondents are aware of the pollution levels in order to find a statistically significant relationship between pollution and life satisfaction. The subjective well-being indicator should capture indirect effects of externalities on individuals' utility through effects on health and the like, even if there are no direct effects (Frey and Stutzer, 2005, p. 220). Secondly, the main source of $\mathrm{SO}_{2}$ emissions is fossil fuel combustion at power plants and other industrial facilities, as opposed to non-stationary emitters (e.g., road transport in the case of $\mathrm{CO}, \mathrm{NO}_{2}$ and $\left.\mathrm{PM}_{10}\right){ }^{5}$ Thus, while $\mathrm{SO}_{2}$ is a regional pollutant, the impacts of other pollutants are more localized (see, e.g., de Kulizenaar et al, 2001). Empirical analyses should use a finer level of disaggregation for the local pollutants. In Berlin, for example, $\mathrm{PM}_{10}$ concentrations at kerbside sites on main streets are up to $40 \%$ higher than in the urban background (Lenschow et al., 2001). We were not able to match individual respondents to accurate data on local pollution. The smallest spatial units at

\footnotetext{
${ }^{3}$ In the Commission, we also find Nobel Prize laureates Kenneth Arrow, James Heckman, and Daniel Kahneman, and prominent subject experts (Angus Deaton, Robert Putnam, Nicholas Stern, Andrew Oswald, and Alan Krueger).

${ }^{4} \mathrm{http}$ ///ec.europa.eu/environment/air/quality/legislation/existing_leg.htm.

${ }^{5}$ In the case of Ireland, for example, over $50 \%$ of total $\mathrm{SO}_{2}$ emissions originate from one location in the West of Ireland (de Kulizenaar et al., 2001).
} 
which ESS data are available are NUTS 3 regions. ${ }^{6}$ In this context, using a regional rather than a local pollutant takes full advantage of the regional nature of our dataset.

The rest of the paper is organized as follows. In the next section we describe the data. Section three presents the empirical approach and section four the results. Section five concludes.

\section{Data}

\subsection{Survey data}

We use individual survey data from the first three waves of the ESS. The ESS is a biennial, cross-sectional, multi-country survey covering over 30 nations. It was fielded for the first time in $2002 / 2003 .^{7}$ ESS data are obtained using random (probability) samples, where the sampling strategies, which may vary by country, are designed to ensure representativeness and comparability across European countries. We use the first three waves of the ESS dataset in this paper which include approximately 75,000 observations from 23 European countries. ${ }^{8}$

To capture subjective well-being, we use the answers to the following lifesatisfaction question: "All things considered, how satisfied are you with your life as a whole nowadays?" Respondents were shown a card, where 0 means extremely dissatisfied and 10 means extremely satisfied. Figure 1 shows the average life satisfaction levels across the regions covered by the ESS over the three rounds, that is, between 2002 and 2007. Overall, Europeans report high levels of life satisfaction (7.12

\footnotetext{
${ }^{6}$ The Nomenclature of Territorial Units (NUTS after the French Nomenclature d'Unites Territoriales Statistiques) is a geocode standard for referencing the subdivisions of countries for statistical purposes. There is a 3-level hierarchy for each EU member country with NUTS 3 referring to the smallest subdivision.

${ }^{7}$ See www.europeansocialsurvey.org.
} 
on average), and the levels are especially high in Nordic countries (from 7.74 in Norway to 8.49 in Denmark). The lowest levels of life satisfaction among the countries in the ESS are found in Portugal (5.47) and in Eastern European countries (5.51 in Hungary and 5.80 in Slovakia). These results are in line with previous findings in cross-country studies using other similar datasets (see e.g., World Values Survey, 2011). Figure 1 also shows that there are notable variations in life satisfaction across regions within countries. For example, average life satisfaction in Italy ranges from 5.57 in Sardinia to 7.80 in Valle d'Aosta.

\section{>> Figure 1}

The explanatory variables at the individual level include socio-economic and socio-demographic characteristics, and we have selected variables that have been found in previous studies to have an impact on subjective well-being (age, sex, marital status, household composition, educational level, employment status, household income, and citizenship of the country of residence) (see e.g., Dolan et al., 2008). The ESS also collects information on a number of variables that have been used to proxy for personal functioning/feelings (e.g., self-reported health and religiosity) that also influence subjective well-being and are typically included as additional individual controls in the literature. Table 1 contains the variable descriptions and Table 2 the descriptive statistics of the variables used in our empirical analysis.

\section{>> Table 1}

\footnotetext{
${ }^{8}$ The countries included in our analysis are Austria, Belgium, Czech Republic, Switzerland, Germany, Denmark, Estonia, Spain, Finland, France, Greece, Hungary, Ireland, Italy, Luxembourg, Netherlands,
} 


\section{>> Table 2}

\subsection{Measuring air quality}

We collected data on the annual mean $\mathrm{SO}_{2}$ concentrations from a network of monitoring stations in 23 European countries between 2002 and 2007 from AirBase, the public air quality database system of the European Environmental Agency. ${ }^{9}$ Monitoring stations are represented as point data, i.e., XY coordinates. However, due to the uneven distribution of monitoring stations and finite national coverage, the concentrations between monitoring stations remains unknown. The solution is to apply spatial interpolation techniques to the available data to provide air quality information between monitoring stations (Denbyl et al., 2010). In this paper, we used a GIS-based interpolation method, namely inverse distance weighting (IDW). IDW is suitable for rapid interpolation of in-situ air quality data, and retains a large number of the original data after interpolation. ${ }^{10}$ In IDW, the weight (influence) of a sampled data point is inversely proportional to its distance from the estimated value, i.e., IDW assumes that each measured point has a local influence that diminishes with distance. It weights the points closer to the prediction location more than those farther away.

The general formula is $\hat{Z}\left(s_{0}\right)=\sum_{i=1}^{N} \lambda_{i} Z\left(s_{i}\right)$, where $\hat{Z}\left(s_{0}\right)$ is the value we are trying to predict, in our case $\mathrm{SO}_{2}$ concentrations, for location $s_{0} ; N$ is the number of measured sample points (monitoring stations) surrounding the prediction location that will be used

Norway, Poland, Portugal, Sweden, Slovenia, Slovakia and the UK.

${ }^{9} \mathrm{http}$ ///acm.eionet.europa.eu/databases/airbase/index_html.

10 Results based on an alternative interpolation method, kriging, were similar. Kriging permits the variogram (i.e., the spatial dependence of the data) to assume different functional forms that include directional dependence. For more details on the interpolation methodology and more detailed information about the dataset see Brereton et al. (2011). 
in the prediction; $Z\left(s_{i}\right)$ is the observed value at the location $s_{i}$, i.e., the actual $\mathrm{SO}_{2}$ readings from the monitoring stations; $\lambda$ are the weights assigned to each measured point. These weights decrease with distance: $\lambda_{i}=d_{i 0}^{-p} / \sum_{i=1}^{N} d_{i 0}^{-p} ; \sum_{i=1}^{N} \lambda_{i}=1$, where $d_{i 0}$ is the distance between the prediction location $s_{0}$ and each of the measured locations $s_{i}$. As the distance becomes larger, the weight is reduced by a factor of $p$ (ESRI, 2003).

To create a European-wide GIS database for air quality $\left(\mathrm{SO}_{2}\right)$ with a grid cell size of $5 \mathrm{~km}$, we applied the IDW interpolation techniques to create a surface of $\mathrm{SO}_{2}$ raster values and then extracted the raster values to vector grids of $5 \times 5 \mathrm{~km}$ resolution. Those values were then transferred to attribute tables and averaged to the NUTS level to be able to do the matching to the survey data (see Brereton et al., 2011 for additional details on the interpolation process). We include 248 regions (corresponding to 23 countries) in the analysis. The final level of regional aggregation (NUTS 1, NUTS 2 or NUTS 3) varies by country and is determined by the level of spatial disaggregation in the ESS. ${ }^{11}$

Figure 2 shows average $\mathrm{SO}_{2}$ concentrations across Europe in 2006. In addition to between-country variation, there is much within-country variation in pollution levels. For example, for Poland, the country with the second highest average concentration of $\mathrm{SO}_{2}$ (at $10.60 \mu \mathrm{g} / \mathrm{m}^{3}$ ), concentrations range between $4.8 \mu \mathrm{g} / \mathrm{m}^{3}$ in the region of Zachodniopomorskie and $21.22 \mu \mathrm{g} / \mathrm{m}^{3}$ in Slaskie. Interestingly, the "greener" countries

\footnotetext{
${ }^{11}$ Austria (NUTS 2, 9 regions included in the analysis), Belgium (NUTS 1, 3 regions), Czech Republic (NUTS 3, 14 regions), Switzerland (NUTS 2, 5 regions), Germany (NUTS 1, 16 regions), Denmark (NUTS 3, 15 regions), Estonia (NUTS 3, 5 regions), Spain (NUTS 2, 17 regions), Finland (NUTS 2, 4 regions), France (NUTS 2, 9 regions), Greece (NUTS 2, 13 regions), Hungary (NUTS 2, 7 regions), Ireland (NUTS 3, 3 regions), Italy (NUTS 2, 19 regions), Luxembourg (NUTS 1, 1 region), Netherlands (NUTS 3, 40 regions), Norway (NUTS 2, 7 regions), Poland (NUTS 2, 16 regions), Portugal (NUTS 2, 5 regions), Sweden (NUTS 3, 8 regions), Slovenia (NUTS 3, 12 regions), Slovakia (NUTS 3, 8 regions) and the UK (NUTS 1, 12 regions).
} 
in Figure 2, Norway and Denmark (with average concentrations of 1.09 and $2.19 \mu \mathrm{g} / \mathrm{m}^{3}$, respectively) are also among the most satisfied in Figure 1.

\section{>> Figure 2}

\subsection{Other regional characteristics}

In order to prevent omitted variable bias, we control for a number of variables that proxy for the economic and demographic characteristics of the area where the respondent lives as well as for the climate conditions. For example, as argued by Luechinger (2009), per capita income and employment may be high in industrialized regions with high $\mathrm{SO}_{2}$ concentrations. We control for the size of the settlement where the respondent lives as stated by the respondent (big city, suburbs, town, small village, or farm/country side). We also collected regional information on population density, GDP per capita and the unemployment rate for the population 15 and above from the European Commission's Eurostat database. ${ }^{12,13}$

Finally, we control for regional climatic conditions. Climate variables, from the European Climate Assessment \& Dataset, ${ }^{14}$ include maximum temperature in July, minimum temperature in January, and mean annual precipitation. We used similar interpolation techniques as for the pollution data. ${ }^{15}$

\footnotetext{
${ }^{12}$ See http://epp.eurostat.ec.europa.eu/portal/page/portal/statistics/search_database

${ }^{13}$ In addition, because the regional macroeconomic variables contain many missing values and when included in the regression reduce the sample size by almost half, we analyzed the robustness of the results to two alternative variables constructed using ESS data: average of the income reported by other respondents in the respondent's region (as a proxy for regional income), and the ratio of the number of unemployed actively seeking work to those in a paid work in the respondent's region (as a proxy for regional unemployment).

${ }^{14}$ See http://eca.knmi.nl/

${ }^{15}$ In addition, we used Climate Data Operators (CDO) software to extract the relevant files and to obtain the values for the relevant variable from daily data. CDO is a collection of tools developed by the Max-
} 
Appendix table 1 shows the correlation coefficients of the individual variables (Panels A and B) and the spatial variables (Panel C). As suggested by Figures 1 and 2 the correlation between life satisfaction and $\mathrm{SO}_{2}$ concentrations (Panel $\mathrm{C}$ ) is negative (-0.125). Interestingly, in our multi-country sample the correlation between $\mathrm{SO}_{2}$ concentrations and regional income (measured either from Eurostat data or using sample averages) is negative, while the correlations with the unemployment rates are positive. This is consistent with richer regions having more stringent regulations or, alternatively, with regions specialized in services and with a lower industry base having higher income per capita and lower $\mathrm{SO}_{2}$ concentrations. In Figure 2 it was evident that the largest concentrations of $\mathrm{SO}_{2}$ occur in Eastern Europe, Greece and western Spain, whose incomes are below the European average.

\section{Econometric methods}

We estimate the following hybrid subjective well-being function (which merges individual and regional-level information in the same equation):

$$
L S_{i j k, t}=\alpha_{k}+\delta_{t}+\boldsymbol{\beta}_{1}^{\prime} \mathbf{X}_{i j k, t}+\boldsymbol{\beta}_{2}^{\prime} \mathbf{Z}_{j k, t}+e_{i j k, t},
$$

where the self-reported life satisfaction, $L S$, of individual $i$, in region $j$, at country $k$, in year $t$ depends on a vector of individual socio-demographic and economic characteristics $\left(\mathbf{X}_{i j k, t}\right)$, and the characteristics of the region where s/he resides, which include annual indicators of pollution, climate, and demographic and economic controls $\left(\mathbf{Z}_{j k, t}\right)$. In equation (1) we control for unobserved country-level and temporal heterogeneity by introducing country $\left(\alpha_{k}\right)$ and time $\left(\delta_{t}\right)$ dummies. In addition, in one

Planck Institute to manipulate, analyze and forecast climate data (see


specification we included regional dummies (at the NUTS 1 level) to help capture omitted geographical characteristics (e.g., proximity to the coast) and socio-political characteristics (e.g., political representation or the level of provision of public services, especially in more decentralized states) that are not well captured by the country dummies or the regional controls.

It should be noted that ESS is a repeated cross-section, not a panel. Hence, we do not control for unobserved individual heterogeneity. Previous studies have addressed unobserved individual heterogeneity by averaging observations across individuals in a country (for example, Welsch 2002; 2006; and Luechinger, 2010), at the cost of ignoring intra-country variability in environmental conditions. While the averaging approach is viable at the national level since the ESS samples at the country level are representative, it is not appropriate at the regional level. ESS samples are not representative at this finer level of spatial disaggregation. ${ }^{16}$ In this paper, we do not fully address individual unobserved heterogeneity in order to take advantage of the rich variation of environmental conditions at the regional level across Europe.

Equation (1) can be estimated by ordinary least squares (OLS) or, given the ordinal nature of the dependent variable, life satisfaction, by using either ordered-probit or ordered-logit models. As in previous studies that have applied both approaches, we find little qualitative difference between the results of the two (see e.g., Ferrer-iCarbonell and Frijters, 2004; or Angrist and Pischke, 2009). Our discussion below focuses on the OLS results as their interpretation is more straightforward. ${ }^{17}$ In all the regressions, standard errors are clustered at the regional level to account for biases

\footnotetext{
http://www.unidata.ucar.edu/software/netcdf/software.html\#CDO).

${ }^{16}$ Www.europeansocialsurvey.org/index.php?option=com_content\&view=article\&id=80\&Itemid=365.

${ }^{17}$ The results of the ordered probit estimation are available upon request.
} 
arising from potential intra-correlation of responses (e.g., Moulton, 1990; Williams, 2000).

\section{Results}

We estimate seven different specifications of the model presented in equation (1). The simplest version, in the first column of Table 3 , is a standard subjective wellbeing regression that includes only individual characteristics $\left(\mathbf{X}_{i j k, t}\right)$ as explanatory variables without inclusion of region-specific variables $\left(\mathbf{Z}_{j k, t}\right)$.

The impacts of individual socio-economic characteristics on subjective wellbeing are similar to those typically found in the literature (e.g., Dolan et al., 2008; Blanchflower and Oswald, 2008). Age has a non-linear, U-shaped, effect on well-being. Being a female, having a higher income and better health, all have a positive and significant impact on life satisfaction. People who are married or in a civil partnership report to be more satisfied with life than singles, while separated and divorced are less content. Regarding employment status, students and retired people report the highest levels of life satisfaction, while those unemployed report the lowest. As we would expect, results in Table 3 indicate that people who report to be in good health are substantially more satisfied with life than those who are in poor health.

The other six specifications of the model presented in equation (1) expand the standard subjective well-being regression by incorporating the spatial variables. In column 2 of Table $3, \mathrm{SO}_{2}$ emerges with a negative and statistically significant coefficient. An increase of $1 \mu \mathrm{g} / \mathrm{m}^{3}$ in $\mathrm{SO}_{2}$ concentrations is associated with a reduction in life satisfaction of 0.016 points on the life satisfaction scale. In order to put this number into perspective, the estimated coefficients of the impact of country-level $\mathrm{SO}_{2}$ 
concentrations on subjective well-being in Luechinger (2010) range between -0.001 and -0.002 with life satisfaction elicited in a 4-point scale (i.e., our estimates using regional instead of country-level data are about three to four times larger). In column 3 of Table 3, we re-estimate the results, but exclude the health status variables. Compared to column 2, the coefficient of $\mathrm{SO}_{2}$ increases in both size and significance (it is now significant at the 5\% level). This suggests that $\mathrm{SO}_{2}$ has indeed an impact on life satisfaction through health, but combined with the results in column 2 , it seems that much of the negative impact of $\mathrm{SO}_{2}$ on life satisfaction that we find in our regressions is a direct effect, not captured by the health-status dummies. ${ }^{18}$

In order to explore more in-depth the relationship between $\mathrm{SO}_{2}$, health and subjective well-being, and to account for both direct and indirect (via health) impacts of $\mathrm{SO}_{2}$ on well-being, we estimated a system of two equations in a seemingly unrelated regression (SUR) specification. In the first equation health explicitly depended on $\mathrm{SO}_{2}$ concentrations, while in the second equation life satisfaction depended on $\mathrm{SO}_{2}$ concentrations and health, conditioning, in both equations, on other micro variables, country and year fixed effects. ${ }^{19}$ The results for the well-being equation (not reported here but available upon request) are virtually identical to those in column 2 of Table 3 . In the health regression, $\mathrm{SO}_{2}$ was insignificant suggesting again that the negative impact of $\mathrm{SO}_{2}$ on life satisfaction captured by the well-being regression is direct, not mediated by the health dummies.

\footnotetext{
${ }^{18}$ The negative impact of $\mathrm{SO}_{2}$ on life satisfaction does not seem to be due to differences in environmental attitudes among respondents either. In regressions not reported in the paper but available upon request, we find that people who report that "the environment" is important also tend to report higher levels of life satisfaction. This is similar to the effect that Ferrer-i-Carbonell and Gowdy (2007) who find for concern about species extinction. However, the size and significance of the $\mathrm{SO}_{2}$ pollution coefficient in column 3 of Table 3 does not change.
} 


\section{>> Table 3}

In column 4 of Table 3, we control for the size of settlement where the respondent lives and for regional differences in climate. Results shown in column 4 are robust to the inclusion of these additional variables. Regarding the impacts of pollution concentrations on life satisfaction, $\mathrm{SO}_{2}$ remains statistically significant, and if anything, its negative effect on life satisfaction is larger than in column 3 in terms of both magnitude and significance, increasing to 0.0213 and significant at the $1 \%$ level. Turning to the size of settlement variables, living in urban areas is associated with lower life satisfaction than living in rural areas; life satisfaction tends to be monotonically reduced as the size of the dwelling area of the respondent increases. Of the climate variables, the coefficients on the January minimum and July maximum temperatures are consistent with preferences for milder climates (although these coefficients are not statistically significant at the conventional levels). Precipitation has a positive and significant impact on life satisfaction, in line with findings in Rehdanz and Maddison (2005) which they explain as possibly due to landscape effects.

In column 5 of Table 3, we complete the list of spatial controls by also including regional macroeconomic variables: unemployment rate, GDP per capita and population density. In this specification, the regional unemployment rate has a negative and significant impact on well-being (as in Clark and Oswald, 1994; and Luechinger et al., 2010). Results for $\mathrm{SO}_{2}$ remain robust, although due to missing observations of the macroeconomic variables the number of observations is reduced by about one third. For robustness, in column 6 we include alternative indicators of unemployment rate and

\footnotetext{
${ }^{19}$ We thank an anonymous reviewer for this suggestion.
} 
average income constructed from ESS data (see Table 1 for exact definitions) and thus without having the same problem of losing many observations as in the previous model. The result for $\mathrm{SO}_{2}$ is similar to what is presented in column 4. The coefficient for average income in this specification, positive and highly significant, suggests that average income captures regional public goods (rather than reference income in a statuscompetition context).

Finally in column 7 of Table 3, when we include regional fixed effects, the coefficient on $\mathrm{SO}_{2}$ remains negative and highly significant and becomes larger in absolute value (-0.03), suggesting that indeed, the regional dummies may help capture omitted geographical or socio-political characteristics for which the country dummies and the regional controls were imperfect proxies.

\section{Conclusions}

In recent years there has been a rapidly increasing interest in subjective wellbeing data among policy-makers for uses ranging from monitoring progress to direct use in policy design. The analysis of the impact of environmental factors on subjective wellbeing at a sub-national level has in the past been limited by data availability, except for studies in local areas (e.g., Van Praag and Baarsma, 2005, study of noise in Amsterdam, or MacKerron and Mourato, 2009, study on air quality in London).

This paper combines rich European data on air pollution, climate and macroeconomic controls using GIS to create a detailed spatially-referenced dataset at the regional level to feed analyses investigating the importance of air quality on individual welfare. This is along the suggested line of research in the overview paper by Welsch and Kühling (2009) when they wrote "Another difficulty is that the spatial and 
temporal matching between happiness and income on the one hand and environmental conditions on the other is sometimes rather crude. In the light of this, improvements in available data sets may be expected to enhance the precision of results" (p. 403).

Our dataset matches regional concentrations of $\mathrm{SO}_{2}$, a pollutant amenable to regional analysis, and that has received considerable attention from policy makers, as well as other spatial controls to individual data from the first three waves of the European Social Survey. This allows us to investigate the relationship between people's subjective well-being levels and air quality at the regional level in Europe. Previous analyses that have analyzed the role of $\mathrm{SO}_{2}$ concentrations (e.g., Luechinger, 2009; 2010; Menz and Welsch 2012) or $\mathrm{SO}_{2}$ emissions (Di Tella and MacCulloch, 2008) on life satisfaction find that pollution negatively affects subjective well-being, but they use country level data or focus on one country only (Luechinger, 2009).

Consistent with previous studies, when using detailed regional data, we find a negative and significant relationship between air pollution and individual self-reported life satisfaction. An increase in $\mathrm{SO}_{2}$ concentrations by $1 \mu \mathrm{g} / \mathrm{m}^{3}$ is associated with a reduction in life satisfaction of between 0.016 and 0.030 points on the 11-point life satisfaction scale. The sign, significance and magnitude of this effect are robust to using different model specifications. We warn, however, that while our analysis, at the regional level, may be appropriate for a regional pollutant such as $\mathrm{SO}_{2}$, it may not extend to other, more local, air pollutants. 


\section{Acknowledgements}

We would like to thank Richard Howarth, Heinz Welsch, and two anonymous reviewers for very helpful comments. Financial support from the European Science Foundation (Cross-National and Multi-level Analysis of Human Values, Institutions and Behaviour (HumVIB)), FAS (Forskningsrådet för Arbetsliv och Socialvetenskap, in English: Swedish Council for Working Life and Social Research) and from Formas through the program Human Cooperation to Manage Natural Resources (COMMONS) is gratefully acknowledged. We would like to thank Victor Peredo Alvarez and Oana Borcan for excellent research assistance. 


\section{References}

Angrist, J., Pischke, J., 2009. Mostly Harmless Econometrics, Princeton University Press.

Blanchflower, D., Oswald, A., 2008. Is well-Being U-shaped over the life cycle?, Social Science and Medicine 66, 1733-1749.

Brereton, F., Clinch, J.P., Ferreira, S., 2008. Happiness, geography and the environment, Ecological Economics 65, 386-396.

Brereton, F., Moro, M., Ningal, T., Ferreira, S., 2011. Technical report on GIS Analysis, Mapping and Linking of Contextual Data to the European Social Survey, Mimeo.

Clark, A. E., Oswald, A., 1994. Unhappiness and unemployment, Economic Journal $104,648-59$.

de Kluizenaar, Y., Aherne, J., Farrell, E.P., 2001. Modelling the spatial distribution of $\mathrm{SO}_{2}$ and NOx emissions in Ireland, Environmental Pollution, 112 (2), $171-182$.

Deaton, A., 2008. Income, health, and well-being around the world: Evidence from the Gallup World Poll, Journal of Economic Perspectives 22 (2), 53 - 72.

Denbyl, B., Garcia, V., HoUand, D. \& Hogrefe, C. 2010. Integration of air quality modeling and monitoring data for enhanced health exposure assessment. EM: Air and Waste Management Associations Magazine for Environmental Managers. Air and Waste Management Association, Pittsburgh, PA, pp. 46-49.

Di Tella, R. and R. J. MacCulloch, 2008. Gross National Happiness as an Answer to the Easterlin Paradox, Journal of Development Economics 86 (1), 22-42.

Dolan, P., Layard, R., Metcalfe, R., 2011. Measuring subjective well-being for public policy, The office for National Statistics, February 2011.

Dolan, P., Peasgood, T., White, M., 2008. Do we really know what makes us happy? A review of the economic literature on the factors associated with subjective wellbeing, Journal of Economic Psychology 29, 94-122.

ESRI (2003) Using ArcGIS Geostatistical Analyst, ESRI Press, Redlands, CA.

Ferrer-i-Carbonell, A., Frijters, P., 2004. How important is methodology for the estimates of the determinants of happiness?, The Economic Journal 114(497), 641-659.

Ferrer-i-Carbonell, A., Gowdy, J.M., 2007. Environmental degradation and happiness?, Ecological Economics 60 (3), 509 - 516. 
Fleurbaey, M., 2009. Beyond GDP: The quest for a measure of social welfare, Journal of Economic Literature 47, 1029-1075.

Folinsbee, L.J., 1992. Human health effects of air pollution, Environmental Health Perspectives 100, 45-56

Frey, B.S., Stutzer, A., 2002. Happiness and economics. Princeton: University Press.

Frey, B.S., Stutzer, A., 2005. Happiness Research: State and Prospects, Review of Social Economy 62(2), 207-228

Kahneman, D., and A. B. Krueger, 2006. Developments in the Measurement of Subjective Well-Being, Journal of Economic Perspectives 20(1), 3-24.

Lenschow, P., H.-J., Abraham, Kutzner, K., Lutz, M., Preuß, J.-D., Reichenbächer, W. 2011. Some ideas about the sources of PM10, Atmospheric Environment, 35 (1), $\mathrm{S} 23-\mathrm{S} 33$.

Levinson, A. 2012. Valuing pulic goods using happiness data: The case of air quality, Journal of Public Economics 96(9-10), 869-880.

Luechinger, S., 2009. Valuing air quality using the life satisfaction approach, Economic Journal 119, 482-515.

Luechinger, S., Raschky, P., 2009. Valuing flood disasters using the life satisfaction approach, Journal of Public Economics 93, 620-33.

Luechinger, S., 2010. Life satisfaction and transboundary air pollution, Economics Letters 107(1), 4-6.

Luechinger, S., S. Meier, Stutzer, A., 2010. Why does unemployment hurt the employed?: Evidence from the life satisfaction gap between the public and the private sector, Journal of Human Resources 45(4), 998-1045

MacKerron, G., 2011. Happiness economics from 35000 feet, Journal of Economic Surveys, Forthcoming.

MacKerron, G., Mourato, S., 2009. Life satisfaction and air quality in London, Ecological Economics 68(5), 1441-1453

Menz, T., Welsch, H., 2010. Population aging and environmental preferences in OECD countries: The case of air pollution, Ecological Economics 69, 2582-2589.

Menz, T., Welsch, H., 2012. Life-Cycle and Cohort Effects in the Valuation of Air Quality: Evidence from Subjective Well-being Data, Land Economics 88 (2), $300-325$. 
Moulton B.R. 1990. An illustration of a pitfall in estimating the effects of aggregate variables on micro unit, The Review of Economics and Statistics 72(2), 334-38

Murray, T., Maddison, D., Rehdanz, R., 2011. Do geographical variations in climate influence life satisfaction? Kiel Working Papers 1694, Kiel Institute for the World Economy.

Rehdanz K., Maddison, D., 2005. Climate and happiness, Ecological Economics 52, $111-125$.

Smyth, R., V. Mishra and X. Qian, 2008. The environment and well-being in urban China, Ecological Economics 68, 547-555.

Stiglitz, J.E., A. Sen, Fitoussi, J.-P., 2009. Commission on the Measurement of Economic Performance and Social Progress, http://www.stiglitz-senfitoussi.fr/documents/rapport_anglais.pdf.

Stutzer, A., Frey, B. S., 2008. Stress that doesn't pay: The commuting paradox, Scandinavian Journal of Economics 110(2), 339-366.

Van Praag B.M.S., Baarsma, B.E., 2005. Using happiness surveys to value intangibles: the case of airport noise, Economic Journal 115, 224-246.

Van Praag, B.M.S., Ferrer-i-Carbonell, A., 2008. Happiness Quantified: A Satisfaction Calculus Approach, Oxford University Press.

Welsch, H., 2002. Preferences over prosperity and pollution: Environmental valuation based on happiness surveys, Kyklos 55, 473-494.

Welsch, H., 2006. Environment and happiness: Valuation of air pollution using life satisfaction data, Ecological Economics 58, 801-813.

Welsch, H., 2007. Environmental welfare analysis: A life satisfaction approach, Ecological Economics 62, 544-551.

Welsch, H., 2009. "Implications of happiness research for environmental economics", Ecological Economics 68, 2735-2742.

Welsch, H., Kühling, J., 2009. Using happiness data for environmental valuation: Issues and applications, Journal of Economic Surveys 23, 385-406.

Williams, R.L., 2000. A note on robust variance estimation for cluster-correlated data, Biometrics 56, 645-646.

World Values Survey 2011. http://www.worldvaluessurvey.org (accessed December 17, 2011). 
Table 1: List of variables

\begin{tabular}{|c|c|c|}
\hline VARIABLE & SOURCE & DESCRIPTION \\
\hline \multicolumn{3}{|l|}{ Individual variables $(\mathrm{Xijt})$} \\
\hline \multicolumn{3}{|l|}{ Socio-demographic } \\
\hline Indicators & ESS & \\
\hline Subjective Well-Being & & $\begin{array}{l}\text { "How satisfied with life as a whole?": } 0 \text { (extremely dissatisfied) } \\
\text { - } 10 \text { (extremely satisfied) }\end{array}$ \\
\hline Sex & & Dummy: $1=$ Female \\
\hline Age & & Age of respondent in years \\
\hline Marital Status & & $\begin{array}{l}4 \text { categories: married or in civil partnership; separated, divorced; } \\
\text { widowed; never married nor in civil partnership (reference) }\end{array}$ \\
\hline Household Income & & Household's total net income (all sources). \\
\hline Employment Status & & $\begin{array}{l}8 \text { categories: paid work; in education; unemployed and actively } \\
\text { looking for job; unemployed and not actively looking for job; } \\
\text { permanently sick or disabled; retired; housework; } \\
\text { community/military service, other (reference category). }\end{array}$ \\
\hline Educational Level & & Years of full-time education completed \\
\hline Household size & & Number of people living regularly as member of household \\
\hline Children & & Dummy: $1=$ Children in the household \\
\hline Citizenship & & Dummy: $1=$ Citizen of country of residence \\
\hline Born in country & & Dummy: $1=$ Born in country of residence \\
\hline $\begin{array}{l}\text { Size of settlement } \\
\text { Personal and interpersonal } \\
\text { feelings and functionings }\end{array}$ & ESS & $\begin{array}{l}5 \text { categories: big city, suburbs, town/small city, village, } \\
\text { farm/country side }\end{array}$ \\
\hline Health Status (self-reported) & & Discrete: 1 (very good) - 5 (very bad) \\
\hline $\begin{array}{l}\text { Religiosity } \\
\text { Important to care for nature } \\
\text { and environment }\end{array}$ & & $\begin{array}{l}\text { Dummy: } 1 \text { = Belonging to a particular religion or denomination } \\
\text { Discrete: } 1 \text { (very much like me) }-6 \text { (not like me at all) }\end{array}$ \\
\hline \multicolumn{3}{|c|}{ Regional variables (up to NUTS3 level) $(\mathrm{Zjt})$} \\
\hline$\underline{\text { Pollution }}$ & EEA AirBa & hors \\
\hline $\mathrm{SO} 2$ & & $\mathrm{SO} 2$ mean annual concentration $(\mu \mathrm{g} / \mathrm{m} 3)$ \\
\hline$\underline{\text { Climate }}$ & ECA/Autho & \\
\hline July max temperature & & Mean of daily max. temperature in July $\left({ }^{\circ} \mathrm{C}\right)$ \\
\hline Jan min temperature & & Mean of daily min. temperature in January $\left({ }^{\circ} \mathrm{C}\right)$ \\
\hline Mean annual precipitation & & Annual mean precipitation (mm) \\
\hline$\underline{\text { Socioeconomic structure }}$ & Eurostat $+\mathrm{E}$ & thors \\
\hline GDP per capita & & $\begin{array}{l}\text { Regional gross domestic product (PPP per inhabitant) by } \\
\text { NUTS } 2 \text { regions }\end{array}$ \\
\hline Population density & & Population density by NUTS 2 region \\
\hline Unemployment rate & & Unemployment rate by NUTS 2 region \\
\hline $\begin{array}{l}\text { Sample average regional } \\
\text { household income }\end{array}$ & & $\begin{array}{l}\text { Ln(average income reported by other respondents in respondent's } \\
\text { region) }\end{array}$ \\
\hline $\begin{array}{l}\text { Sample regional } \\
\text { unemployment rate }\end{array}$ & & $\begin{array}{l}\text { Ratio of number of unemployed actively seeking work to those in a } \\
\text { paid work in the respondent's region }\end{array}$ \\
\hline
\end{tabular}

Note. For more information on pollution and climate variables see Brereton et al. (2011). 
Table 2: Descriptive statistics

\begin{tabular}{|c|c|c|c|c|c|}
\hline Variable & Obs & Mean & Std. Dev. & Min & Max \\
\hline Life Satisfaction & 81306 & 7.12 & 2.17 & 0 & 10 \\
\hline Income & 81306 & 34,975 & 29,858 & 900 & 150,000 \\
\hline \multicolumn{6}{|c|}{ Employment status (ref: community/military service, other) } \\
\hline Paid work & 81306 & 0.55 & 0.50 & 0 & 1 \\
\hline Student & 81306 & 0.08 & 0.27 & 0 & 1 \\
\hline Unemployed seeking & 81306 & 0.04 & 0.19 & 0 & 1 \\
\hline Unemployed not seeking & 81306 & 0.02 & 0.14 & 0 & 1 \\
\hline Disabled & 81306 & 0.03 & 0.17 & 0 & 1 \\
\hline Retired & 81306 & 0.24 & 0.43 & 0 & 1 \\
\hline Housework & 81306 & 0.23 & 0.42 & 0 & 1 \\
\hline Years of education & 81306 & 12.03 & 4.07 & 0 & 30 \\
\hline \multicolumn{6}{|c|}{ Marital status(ref: never married) } \\
\hline Married/partner & 81306 & 0.55 & 0.50 & 0 & 1 \\
\hline Separated/divorced & 81306 & 0.10 & 0.29 & 0 & 1 \\
\hline Widowed & 81306 & 0.09 & 0.29 & 0 & 1 \\
\hline Sex: female & 81306 & 0.52 & 0.50 & 0 & 1 \\
\hline Age & 81306 & 47.75 & 17.69 & 14 & 110 \\
\hline Household size & 81306 & 2.70 & 1.40 & 1 & 15 \\
\hline Children & 81306 & 0.40 & 0.49 & 0 & 1 \\
\hline Religiosity & 81306 & 0.61 & 0.49 & 0 & 1 \\
\hline Born in country & 81306 & 0.92 & 0.27 & 0 & 1 \\
\hline Citizen of country & 81306 & 0.96 & 0.19 & 0 & 1 \\
\hline \multicolumn{6}{|c|}{ Health status(ref: bad and very bad health) } \\
\hline Very good health & 81306 & 0.23 & 0.42 & 0 & 1 \\
\hline Good health & 81306 & 0.44 & 0.50 & 0 & 1 \\
\hline Fair health & 81306 & 0.25 & 0.43 & 0 & 1 \\
\hline Environment important & 76098 & 2.13 & 1.00 & 1 & 6 \\
\hline \multicolumn{6}{|l|}{ Pollution } \\
\hline $\mathrm{SO}_{2}$ & 77297 & 5.37 & 3.74 & 0.48 & 27.17 \\
\hline \multicolumn{6}{|l|}{ Size of settlement } \\
\hline Big city & 81142 & 0.17 & 0.38 & 0 & 1 \\
\hline Suburbs & 81142 & 0.14 & 0.35 & 0 & 1 \\
\hline Town & 81142 & 0.31 & 0.46 & 0 & 1 \\
\hline Village & 81142 & 0.31 & 0.46 & 0 & 1 \\
\hline \multicolumn{6}{|l|}{ Climate } \\
\hline Max temperature & 77213 & 24.01 & 4.01 & 5.67 & 35 \\
\hline Min temperature & 77297 & -1.94 & 4.99 & -43 & 10 \\
\hline Precipitation & 71401 & 2.26 & 0.90 & 0 & 6 \\
\hline \multicolumn{6}{|l|}{ Macroeconomic variables } \\
\hline Unemployment rate & 60425 & 8.30 & 5.24 & 1.3 & 26.7 \\
\hline GDP per capita & 49431 & 23,116 & 10,036 & 6,900 & 57,100 \\
\hline Population density & 57861 & 416.90 & 798.08 & 4.3 & 6458.7 \\
\hline
\end{tabular}


In-sample Macroeconomic variables

Unemployment rate 81233

0.08

0.15

0

5.83

Average income

81306

34,931

15,827

5,478

98,667 
Table 3: Life satisfaction and air pollution

\begin{tabular}{|c|c|c|c|c|c|c|c|}
\hline \multirow[b]{2}{*}{ Variables } & \multirow[b]{2}{*}{$\begin{array}{c}\text { Standard LS } \\
\\
\text { (1) } \\
\end{array}$} & \multicolumn{5}{|c|}{ Including $\mathrm{SO}_{2}$ pollution variable } & \multirow[b]{2}{*}{$\begin{array}{c}\text { No health } \\
\text { controls + all } \\
\text { other } \\
\text { controls } \\
\text { +regional } \\
\text { dummies } \\
\\
(7) \\
\end{array}$} \\
\hline & & $\begin{array}{l}\text { With health } \\
\text { controls }\end{array}$ & $\begin{array}{c}\text { No health } \\
\text { controls }\end{array}$ & $\begin{array}{c}\text { No health } \\
\text { controls+ } \\
\text { spatial controls }\end{array}$ & $\begin{array}{c}\text { No health } \\
\text { controls+ spatial } \\
\text { controls }+ \\
\text { macro controls }\end{array}$ & $\begin{array}{l}\text { No health } \\
\text { controls+ } \\
\text { spatial } \\
\text { controls + (in } \\
\text { sample) } \\
\text { macro } \\
\text { controls } \\
\text { (6) }\end{array}$ & \\
\hline Ln(Income) & $\begin{array}{c}0.298 * * * \\
(0.0195)\end{array}$ & $\begin{array}{c}0.294 * * * \\
(0.0201)\end{array}$ & $\begin{array}{c}0.355 * * * \\
(0.0211)\end{array}$ & $\begin{array}{c}0.372 * * * \\
(0.0222)\end{array}$ & $\begin{array}{c}0.383 * * * \\
(0.0249)\end{array}$ & $\begin{array}{c}0.362 * * * \\
(0.0215)\end{array}$ & $\begin{array}{c}0.361 * * * \\
(0.0213)\end{array}$ \\
\hline \multicolumn{8}{|c|}{ Employment Status (ref: community/military service, other) } \\
\hline Paid work & $\begin{array}{c}-0.0183 \\
(0.0264)\end{array}$ & $\begin{array}{c}-0.0251 \\
(0.0270)\end{array}$ & $\begin{array}{c}0.0447 \\
(0.0292)\end{array}$ & $\begin{array}{c}0.0338 \\
(0.0310)\end{array}$ & $\begin{array}{c}0.0162 \\
(0.0402)\end{array}$ & $\begin{array}{c}0.0351 \\
(0.0306)\end{array}$ & $\begin{array}{c}0.0316 \\
(0.0303)\end{array}$ \\
\hline Student & $\begin{array}{c}0.202 * * * \\
(0.0357)\end{array}$ & $\begin{array}{c}0.215 * * * \\
(0.0363)\end{array}$ & $\begin{array}{c}0.271 * * * \\
(0.0377)\end{array}$ & $\begin{array}{c}0.289 * * * \\
(0.0393)\end{array}$ & $\begin{array}{c}0.339 * * * \\
(0.0535)\end{array}$ & $\begin{array}{c}0.287 * * * \\
(0.0384)\end{array}$ & $\begin{array}{c}0.284 * * * \\
(0.0394)\end{array}$ \\
\hline Unemployed seeking & $\begin{array}{c}-1.046 * * * \\
(0.0692)\end{array}$ & $\begin{array}{c}-1.059 * * * \\
(0.0718)\end{array}$ & $\begin{array}{c}-1.066 * * * \\
(0.0736)\end{array}$ & $\begin{array}{c}-1.080 * * * \\
(0.0770)\end{array}$ & $\begin{array}{c}-1.148 * * * \\
(0.0897)\end{array}$ & $\begin{array}{c}-1.091 * * * \\
(0.0762)\end{array}$ & $\begin{array}{c}-1.077 * * * \\
(0.0744)\end{array}$ \\
\hline Unemployed not seeking & $\begin{array}{c}-0.628 * * * \\
(0.0914)\end{array}$ & $\begin{array}{c}-0.613 * * * \\
(0.0933)\end{array}$ & $\begin{array}{c}-0.664 * * * \\
(0.0971)\end{array}$ & $\begin{array}{c}-0.683 * * * \\
(0.0986)\end{array}$ & $\begin{array}{c}-0.665 * * * \\
(0.113)\end{array}$ & $\begin{array}{c}-0.682 * * * \\
(0.0985)\end{array}$ & $\begin{array}{c}-0.669 * * * \\
(0.0971)\end{array}$ \\
\hline Disabled & $\begin{array}{c}-0.305 * * * \\
(0.0522)\end{array}$ & $\begin{array}{c}-0.337 * * * \\
(0.0524)\end{array}$ & $\begin{array}{c}-1.117 * * * \\
(0.0564)\end{array}$ & $\begin{array}{c}-1.118 * * * \\
(0.0583)\end{array}$ & $\begin{array}{c}-1.069 * * * \\
(0.0645)\end{array}$ & $\begin{array}{c}-1.118 * * * \\
(0.0579)\end{array}$ & $\begin{array}{c}-1.123 * * * \\
(0.0585)\end{array}$ \\
\hline Retired & $\begin{array}{c}0.197 * * * \\
(0.0344)\end{array}$ & $\begin{array}{c}0.185^{* * *} * \\
(0.0345)\end{array}$ & $\begin{array}{c}0.0813 * * \\
(0.0403)\end{array}$ & $\begin{array}{c}0.0634 \\
(0.0407)\end{array}$ & $\begin{array}{c}0.0290 \\
(0.0530)\end{array}$ & $\begin{array}{c}0.0649 \\
(0.0411)\end{array}$ & $\begin{array}{l}0.0693 * \\
(0.0412)\end{array}$ \\
\hline Housework & $\begin{array}{l}0.0368^{*} \\
(0.0208)\end{array}$ & $\begin{array}{c}0.0340 \\
(0.0214)\end{array}$ & $\begin{array}{l}0.0423^{*} \\
(0.0234)\end{array}$ & $\begin{array}{l}0.0450^{*} \\
(0.0236)\end{array}$ & $\begin{array}{c}0.0215 \\
(0.0326)\end{array}$ & $\begin{array}{l}0.0437^{*} \\
(0.0233)\end{array}$ & $\begin{array}{c}0.0314 \\
(0.0236)\end{array}$ \\
\hline Education & $\begin{array}{c}0.0145^{* * *} * \\
(0.00336)\end{array}$ & $\begin{array}{c}0.0161 * * * \\
(0.00343)\end{array}$ & $\begin{array}{c}0.0311 * * * \\
(0.00361)\end{array}$ & $\begin{array}{c}0.0340^{* * * *} \\
(0.00354)\end{array}$ & $\begin{array}{c}0.0401 * * * \\
(0.00430)\end{array}$ & $\begin{array}{c}0.0333 * * * \\
(0.00349)\end{array}$ & $\begin{array}{c}0.0333 * * * \\
(0.00353)\end{array}$ \\
\hline \multicolumn{8}{|c|}{ Marital Status (ref: Never married) } \\
\hline Married/partner & $\begin{array}{c}0.374 * * * \\
(0.0234)\end{array}$ & $\begin{array}{c}0.377 * * * \\
(0.0248)\end{array}$ & $\begin{array}{c}0.418 * * * \\
(0.0264)\end{array}$ & $\begin{array}{c}0.406 * * * \\
(0.0267)\end{array}$ & $\begin{array}{c}0.457 * * * \\
(0.0337)\end{array}$ & $\begin{array}{c}0.404 * * * \\
(0.0264)\end{array}$ & $\begin{array}{c}0.408 * * * \\
(0.0261)\end{array}$ \\
\hline Separated/divorced & $\begin{array}{c}-0.158 * * * \\
(0.0334)\end{array}$ & $\begin{array}{c}-0.155 * * * \\
(0.0342)\end{array}$ & $\begin{array}{c}-0.135^{* * *} \\
(0.0361)\end{array}$ & $\begin{array}{c}-0.132 * * * \\
(0.0377)\end{array}$ & $\begin{array}{l}-0.117 * * \\
(0.0490)\end{array}$ & $\begin{array}{c}-0.134 * * * \\
(0.0373)\end{array}$ & $\begin{array}{c}-0.128 * * * \\
(0.0371)\end{array}$ \\
\hline Widowed & $\begin{array}{l}-0.0534 \\
(0.0370)\end{array}$ & $\begin{array}{l}-0.0457 \\
(0.0383)\end{array}$ & $\begin{array}{l}-0.0596 \\
(0.0410)\end{array}$ & $\begin{array}{l}-0.0596 \\
(0.0441)\end{array}$ & $\begin{array}{l}-0.0573 \\
(0.0518)\end{array}$ & $\begin{array}{l}-0.0611 \\
(0.0437)\end{array}$ & $\begin{array}{l}-0.0548 \\
(0.0431)\end{array}$ \\
\hline Sex $($ female $=1)$ & $\begin{array}{c}0.146 * * * \\
(0.0147)\end{array}$ & $\begin{array}{c}0.145 * * * \\
(0.0151)\end{array}$ & $\begin{array}{c}0.109 * * * \\
(0.0166)\end{array}$ & $\begin{array}{c}0.108 * * * \\
(0.0171)\end{array}$ & $\begin{array}{c}0.118 * * * \\
(0.0209)\end{array}$ & $\begin{array}{c}0.108 * * * \\
(0.0170)\end{array}$ & $\begin{array}{c}0.114 * * * \\
(0.0170)\end{array}$ \\
\hline Age & $\begin{array}{c}-0.0467 * * * \\
(0.00386)\end{array}$ & $\begin{array}{c}-0.0464 * * * \\
(0.00395)\end{array}$ & $\begin{array}{c}-0.0587 * * * \\
(0.00451)\end{array}$ & $\begin{array}{c}-0.0613 * * * \\
(0.00490)\end{array}$ & $\begin{array}{c}-0.0672 * * * \\
(0.00648)\end{array}$ & $\begin{array}{c}-0.0609 * * * \\
(0.00488)\end{array}$ & $\begin{array}{c}-0.0606 * * * \\
(0.00484)\end{array}$ \\
\hline Age squared /100 & $\begin{array}{c}0.0525 * * * \\
(0.00393)\end{array}$ & $\begin{array}{c}0.0524 * * * \\
(0.00403)\end{array}$ & $\begin{array}{c}0.0578 * * * \\
(0.00459)\end{array}$ & $\begin{array}{c}0.0607 * * * \\
(0.00501)\end{array}$ & $\begin{array}{c}0.0661 * * * \\
(0.00648)\end{array}$ & $\begin{array}{c}0.0604 * * * \\
(0.00500)\end{array}$ & $\begin{array}{c}0.0600 * * * \\
(0.00496)\end{array}$ \\
\hline Household size & $\begin{array}{c}0.0268 * * * \\
(0.00833)\end{array}$ & $\begin{array}{c}0.0279 * * * \\
(0.00848)\end{array}$ & $\begin{array}{c}0.0312 * * * \\
(0.00863)\end{array}$ & $\begin{array}{l}0.0191 * * \\
(0.00892)\end{array}$ & $\begin{array}{l}0.0206^{*} \\
(0.0113)\end{array}$ & $\begin{array}{l}0.0203 * * \\
(0.00870)\end{array}$ & $\begin{array}{l}0.0233 * * * \\
(0.00877)\end{array}$ \\
\hline Children & $\begin{array}{c}-0.136 * * * \\
(0.0233)\end{array}$ & $\begin{array}{c}-0.142 * * * \\
(0.0237)\end{array}$ & $\begin{array}{c}-0.163 * * * \\
(0.0244)\end{array}$ & $\begin{array}{c}-0.154 * * * \\
(0.0253)\end{array}$ & $\begin{array}{c}-0.173 * * * \\
(0.0343)\end{array}$ & $\begin{array}{c}-0.154 * * * \\
(0.0249)\end{array}$ & $\begin{array}{c}-0.157 * * * \\
(0.0245)\end{array}$ \\
\hline Religiosity & $\begin{array}{c}0.190 * * * \\
(0.0216)\end{array}$ & $\begin{array}{c}0.193 * * * \\
(0.0225)\end{array}$ & $\begin{array}{c}0.203 * * * \\
(0.0235)\end{array}$ & $\begin{array}{c}0.194 * * * \\
(0.0244)\end{array}$ & $\begin{array}{c}0.232 * * * \\
(0.0305)\end{array}$ & $\begin{array}{c}0.192 * * * \\
(0.0234)\end{array}$ & $\begin{array}{c}0.161 * * * \\
(0.0199)\end{array}$ \\
\hline Born in country & $\begin{array}{l}0.202 * * * \\
(0.0343)\end{array}$ & $\begin{array}{l}0.202 * * * \\
(0.0347)\end{array}$ & $\begin{array}{c}0.229 * * * \\
(0.0364)\end{array}$ & $\begin{array}{l}0.195^{* * * *} \\
(0.0377)\end{array}$ & $\begin{array}{l}0.219^{* * * *} \\
(0.0480)\end{array}$ & $\begin{array}{l}0.200 * * * \\
(0.0375)\end{array}$ & $\begin{array}{l}0.203 * * * \\
(0.0361)\end{array}$ \\
\hline Citizen in country & $\begin{array}{l}0.109^{* *} \\
(0.0456)\end{array}$ & $\begin{array}{l}0.108^{* *} \\
(0.0473)\end{array}$ & $\begin{array}{l}0.0916^{*} \\
(0.0487)\end{array}$ & $\begin{array}{l}0.0832 * \\
(0.0498)\end{array}$ & $\begin{array}{c}0.0685 \\
(0.0666)\end{array}$ & $\begin{array}{l}0.0835^{*} \\
(0.0497)\end{array}$ & $\begin{array}{l}0.0865^{*} \\
(0.0506)\end{array}$ \\
\hline Health Status(ref: Very bad & ad health) & & & & & & \\
\hline Very good health & $\begin{array}{l}2.202 * * * \\
(0.0500)\end{array}$ & $\begin{array}{c}2.188 * * * \\
(0.0517)\end{array}$ & & & & & \\
\hline Good health & $\begin{array}{l}1.707 * * * \\
(0.0447)\end{array}$ & $\begin{array}{l}1.701 * * * \\
(0.0459)\end{array}$ & & & & & \\
\hline Fair health & $\begin{array}{l}1.109 * * * \\
(0.0413)\end{array}$ & $\begin{array}{l}1.106 * * * \\
(0.0422)\end{array}$ & & & & & \\
\hline Pollution & & & & & & & \\
\hline $\mathrm{SO}_{2}$ & & $\begin{array}{l}-0.0160 * \\
(0.00814)\end{array}$ & $\begin{array}{c}-\mathbf{0 . 0 1 7 4} * * \\
(\mathbf{0 . 0 0 8 0 5 )}\end{array}$ & $\begin{array}{c}-0.0213 * * * \\
(0.00764)\end{array}$ & $\begin{array}{c}-\mathbf{0 . 0 1 8 5} * * \\
(\mathbf{0 . 0 0 7 5 3 )}\end{array}$ & $\begin{array}{c}-\mathbf{0 . 0 2 1 3} * * * \\
(0.00817)\end{array}$ & $\begin{array}{c}-0.0302 * * * \\
(0.00947)\end{array}$ \\
\hline $\begin{array}{l}\text { Size of settlement } \\
\text { Big city }\end{array}$ & & & & $-0.255^{* * *}$ & $-0.148 * *$ & $-0.264 * * *$ & $-0.232 * * *$ \\
\hline
\end{tabular}


Suburbs

Town

Village

Climate variables

Avg min temperature Jan

Avg max temperature July

Precipitation

Macro variables Eurostat

Unemployment rate

GDP per capita

Population density

Macro variables (in sample)

$\mathrm{Ln}$ (average income)

Unemployment rate

\begin{tabular}{lccccccc} 
Country F.E. & Yes & Yes & Yes & Yes & \multicolumn{2}{c}{ Yes } & Yes \\
Region FE \\
Year F.E. & Yes & Yes & Yes & Yes & Yes & Yes & Yes \\
Observations & 81306 & 77297 & 77329 & 71280 & 43874 & 71214 \\
R-squared & 0.252 & 0.252 & 0.201 & 0.200 & 0.188 & 0.200 \\
\hline
\end{tabular}

\begin{tabular}{|c|c|c|c|}
\hline$(0.0516)$ & $(0.0672)$ & $(0.0517)$ & $(0.0532)$ \\
\hline$-0.244 * * *$ & $-0.133 * *$ & $-0.259 * * *$ & $-0.241 * * *$ \\
\hline$(0.0476)$ & $(0.0650)$ & $(0.0480)$ & $(0.0490)$ \\
\hline$-0.230 * * *$ & $-0.153 * *$ & $-0.235 * * *$ & $-0.214 * * *$ \\
\hline$(0.0464)$ & $(0.0615)$ & $(0.0463)$ & $(0.0477)$ \\
\hline$-0.114 * * *$ & -0.0349 & $-0.120 * * *$ & $-0.108 * *$ \\
\hline$(0.0414)$ & $(0.0550)$ & $(0.0414)$ & $(0.0426)$ \\
\hline 0.00279 & 0.00736 & 0.00130 & 0.000973 \\
\hline$(0.00833)$ & $(0.0128)$ & $(0.00846)$ & $(0.00776)$ \\
\hline-0.00792 & -0.00825 & -0.0106 & $-0.0167 * *$ \\
\hline$(0.00825)$ & $(0.0101)$ & $(0.00809)$ & $(0.00837)$ \\
\hline $0.0691 * *$ & $0.0622 *$ & $0.0693 * * *$ & $0.0478 *$ \\
\hline \multirow[t]{11}{*}{$(0.0267)$} & $(0.0374)$ & $(0.0265)$ & $(0.0255)$ \\
\hline & $-0.0404 * * *$ & & \\
\hline & $(0.00641)$ & & \\
\hline & $5.36 \mathrm{e}-07$ & & \\
\hline & $(3.25 \mathrm{e}-06)$ & & \\
\hline & $-2.05 e-05$ & & \\
\hline & $(2.34 \mathrm{e}-05)$ & & \\
\hline & & $0.293 * * *$ & 0.106 \\
\hline & & $(0.107)$ & $(0.110)$ \\
\hline & & 0.149 & $0.194 * *$ \\
\hline & & $(0.159)$ & $(0.0821)$ \\
\hline Yes & Yes & Yes & Region FE \\
\hline Yes & Yes & Yes & Yes \\
\hline 71280 & 43874 & 71214 & 71214 \\
\hline 0.200 & 0.188 & 0.200 & 0.205 \\
\hline
\end{tabular}

Note: Robust standard errors in parentheses; $* * * p<0.01,{ }^{* *} \mathrm{p}<0.05, * \mathrm{p}<0.1$ 
Appendix Table 1: Correlation matrices

Panel A: Individual characteristics

\begin{tabular}{|c|c|c|c|c|c|c|c|c|c|c|c|c|}
\hline & LS & Income & Paid work & Student & $\begin{array}{c}\text { Unemployed L } \\
\text { (seek) }\end{array}$ & $\begin{array}{l}\text { Jnemployed } \\
\text { (not seek) }\end{array}$ & Disabled & Retired & Housework & Education & $\begin{array}{c}\text { Married/ } \\
\text { Partner }\end{array}$ & $\begin{array}{c}\text { Separated/ } \\
\text { Divorced }\end{array}$ \\
\hline Income & 0.2528 & 1 & & & & & & & & & & \\
\hline Paid work & 0.0953 & 0.2918 & 1 & & & & & & & & & \\
\hline Student & 0.0604 & -0.0259 & -0.1751 & 1 & & & & & & & & \\
\hline Unemployed (seek) & -0.1361 & -0.0896 & -0.1965 & -0.0319 & 1 & & & & & & & \\
\hline Unemployed (not seek) & -0.0739 & -0.0664 & -0.1456 & -0.0191 & -0.023 & 1 & & & & & & \\
\hline Disabled & -0.1066 & -0.0569 & -0.1653 & -0.0438 & -0.0197 & 0.0066 & 1 & & & & & \\
\hline Retired & -0.0244 & -0.2126 & -0.5946 & -0.1641 & -0.1087 & -0.0752 & -0.0153 & 1 & & & & \\
\hline Housework & 0.0172 & 0.0142 & -0.1004 & -0.0494 & -0.0207 & 0.0005 & 0.0077 & -0.1045 & 1 & & & \\
\hline Education & 0.15 & 0.322 & 0.3148 & 0.0811 & 0.0067 & -0.0249 & -0.0519 & -0.2915 & -0.0083 & 1 & & \\
\hline Married/partner & 0.0835 & 0.1502 & 0.0831 & -0.2535 & -0.0624 & -0.0265 & -0.0219 & 0.0198 & 0.1163 & -0.0176 & 1 & \\
\hline Separated/Divorced & -0.0764 & -0.0524 & 0.0436 & -0.0645 & 0.0335 & 0.0297 & 0.057 & -0.0292 & -0.0109 & 0.0289 & -0.3604 & 1 \\
\hline Widowed & -0.0733 & -0.1767 & -0.2712 & -0.0895 & -0.0482 & -0.0295 & 0.0169 & 0.3821 & 0.0032 & -0.2208 & -0.3496 & -0.1021 \\
\hline
\end{tabular}

Panel B: Individual characteristics (contn'd)

\begin{tabular}{|c|c|c|c|c|c|c|c|c|c|c|c|}
\hline & LS & Female & Age & $\begin{array}{l}\text { ousehold } \\
\text { Size }\end{array}$ & Children & Religiosity & $\begin{array}{l}\text { Born in } \\
\text { country }\end{array}$ & $\begin{array}{l}\text { Citizen of } \\
\text { country }\end{array}$ & $\begin{array}{l}\text { V. good } \\
\text { health }\end{array}$ & $\begin{array}{l}\text { Good } \\
\text { health }\end{array}$ & Fair health \\
\hline Female & -0.008 & 1 & & & & & & & & & \\
\hline Age & -0.0331 & 0.0261 & 1 & & & & & & & & \\
\hline Household size & 0.0349 & -0.023 & -0.3839 & 1 & & & & & & & \\
\hline Children & -0.0133 & 0.063 & -0.1852 & 0.6324 & 1 & & & & & & \\
\hline Religiosity & -0.0065 & 0.0732 & 0.1617 & 0.0507 & 0.0183 & 1 & & & & & \\
\hline Born in country & 0.0133 & -0.0053 & 0.0453 & -0.0233 & -0.0447 & -0.0131 & 1 & & & & \\
\hline Citizen of counry & 0.0017 & 0.0089 & 0.0842 & -0.0308 & -0.037 & -0.0189 & 0.5826 & 1 & & & \\
\hline V. good health & 0.2061 & -0.036 & -0.2358 & 0.083 & 0.0337 & -0.035 & -0.0269 & -0.0407 & & & \\
\hline
\end{tabular}




\begin{tabular}{lrrrrrrrrrrr} 
Good health & 0.0848 & -0.0305 & -0.1057 & 0.057 & 0.0445 & -0.0401 & 0 & -0.0037 & -0.4911 & 1 & -0.0317 \\
Fair health & -0.1505 & 0.0445 & 0.2244 & -0.0896 & -0.0476 & 0.0486 & 0.0204 & 0.0317 & -0.3154 & -0.5147 & 1 \\
Environment imp. & -0.0272 & -0.0313 & -0.1299 & 0.0404 & 0.0109 & -0.0738 & 0.0143 & 0.0121 & -0.0001 & 0.0179 & -0.0148 \\
\hline
\end{tabular}

\section{Panel C: Regional variables}

\begin{tabular}{|c|c|c|c|c|c|c|c|c|c|c|c|c|c|}
\hline & $\mathrm{LS}$ & $\mathrm{SO}_{2}$ & Big city & Suburbs & Town & Village & $\begin{array}{c}\text { Max. } \\
\text { July } \\
\text { temp. }\end{array}$ & $\begin{array}{l}\text { Min. } \\
\text { Jan. } \\
\text { temp. }\end{array}$ & Precipit. & $\begin{array}{c}\text { Unemp. } \\
\text { rate }\end{array}$ & $\begin{array}{c}\text { GDP per } \\
\text { capita }\end{array}$ & $\begin{array}{c}\text { Pop. } \\
\text { density }\end{array}$ & $\begin{array}{c}\text { In- } \\
\text { sample } \\
\text { avg } \\
\text { income } \\
\end{array}$ \\
\hline $\mathrm{SO}_{2}$ & -0.1245 & 1 & & & & & & & & & & & \\
\hline Big city & -0.0404 & 0.039 & 1 & & & & & & & & & & \\
\hline Suburbs & 0.0162 & -0.0344 & -0.1678 & 1 & & & & & & & & & \\
\hline Town & -0.0311 & -0.0158 & -0.3259 & -0.2494 & 1 & & & & & & & & \\
\hline Village & 0.0271 & 0.048 & -0.3361 & -0.2572 & -0.4996 & 1 & & & & & & & \\
\hline Max. July temp. & -0.1182 & 0.1687 & 0.0846 & -0.0677 & -0.0142 & 0.0308 & 1 & & & & & & \\
\hline Min. Jan. temp. & -0.0087 & -0.0597 & 0.0077 & 0.1106 & -0.0378 & -0.0273 & 0.0995 & 1 & & & & & \\
\hline Precipitation & 0.0556 & -0.0287 & -0.0923 & 0.0375 & -0.0034 & 0.0451 & -0.3508 & 0.2772 & 1 & & & & \\
\hline Unemployment rate & -0.1813 & 0.3418 & 0.0607 & -0.081 & 0.0311 & 0.0008 & 0.1645 & -0.3842 & -0.4196 & 1 & & & \\
\hline GDP per capita & 0.1965 & -0.3799 & 0.097 & 0.1397 & -0.1048 & -0.0699 & -0.1571 & 0.2225 & 0.1231 & -0.5274 & 1 & & \\
\hline Pop density & 0.0198 & -0.0641 & 0.3208 & 0.1342 & -0.1479 & -0.1758 & -0.041 & 0.1491 & -0.0261 & -0.0535 & 0.4119 & 1 & \\
\hline In-sample avg. income & 0.2482 & -0.4806 & -0.0749 & 0.1316 & -0.0227 & -0.035 & -0.3081 & 0.2597 & 0.1868 & -0.5408 & 0.7702 & 0.1938 & 1 \\
\hline In-sample unemp. rate & -0.1548 & 0.1723 & 0.0267 & -0.0635 & 0.0582 & -0.0101 & 0.0822 & -0.1741 & -0.2452 & 0.699 & -0.3915 & -0.0723 & -0.3768 \\
\hline
\end{tabular}




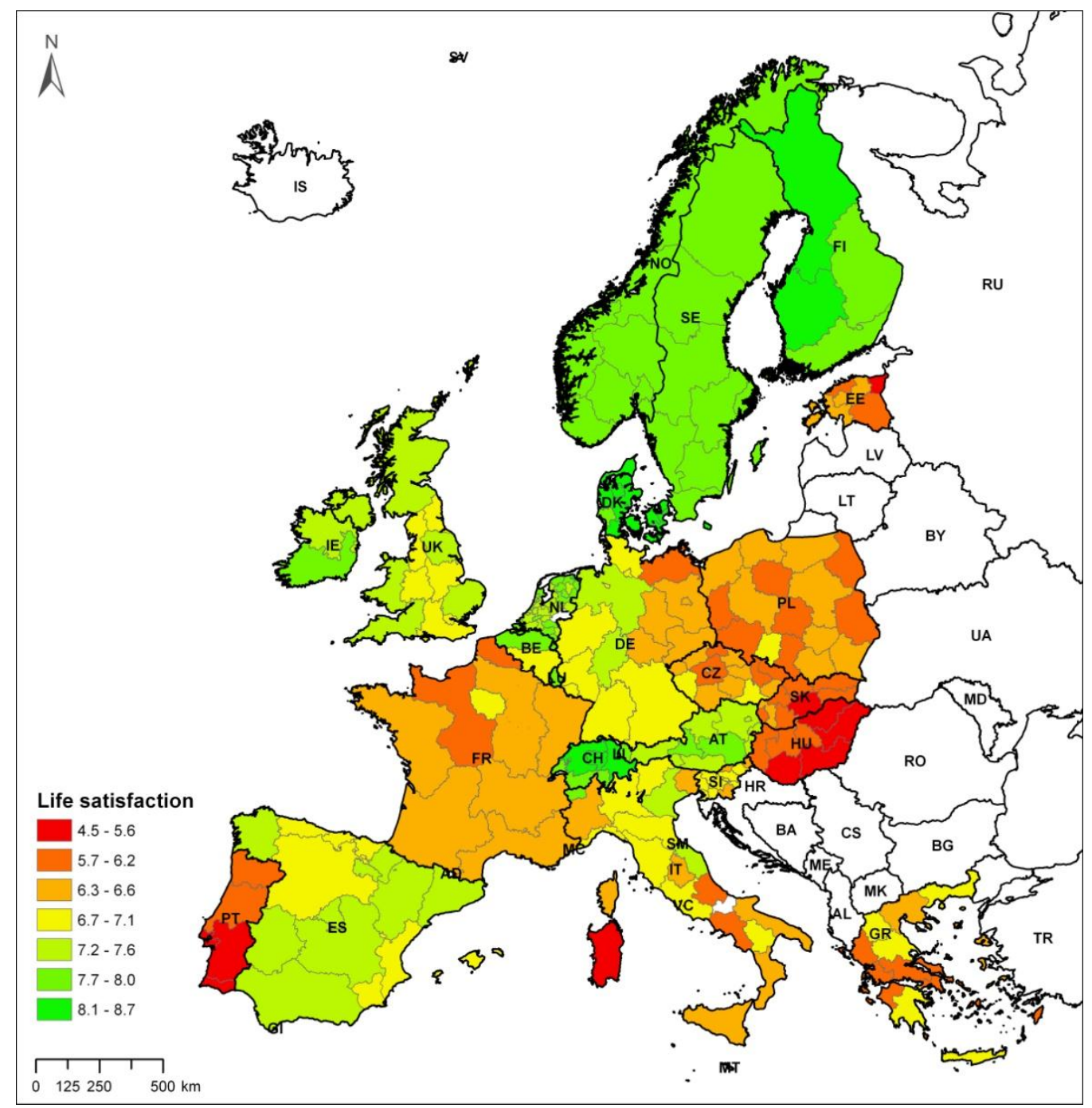

Figure 1: Life Satisfaction in Europe (2002-2007) 


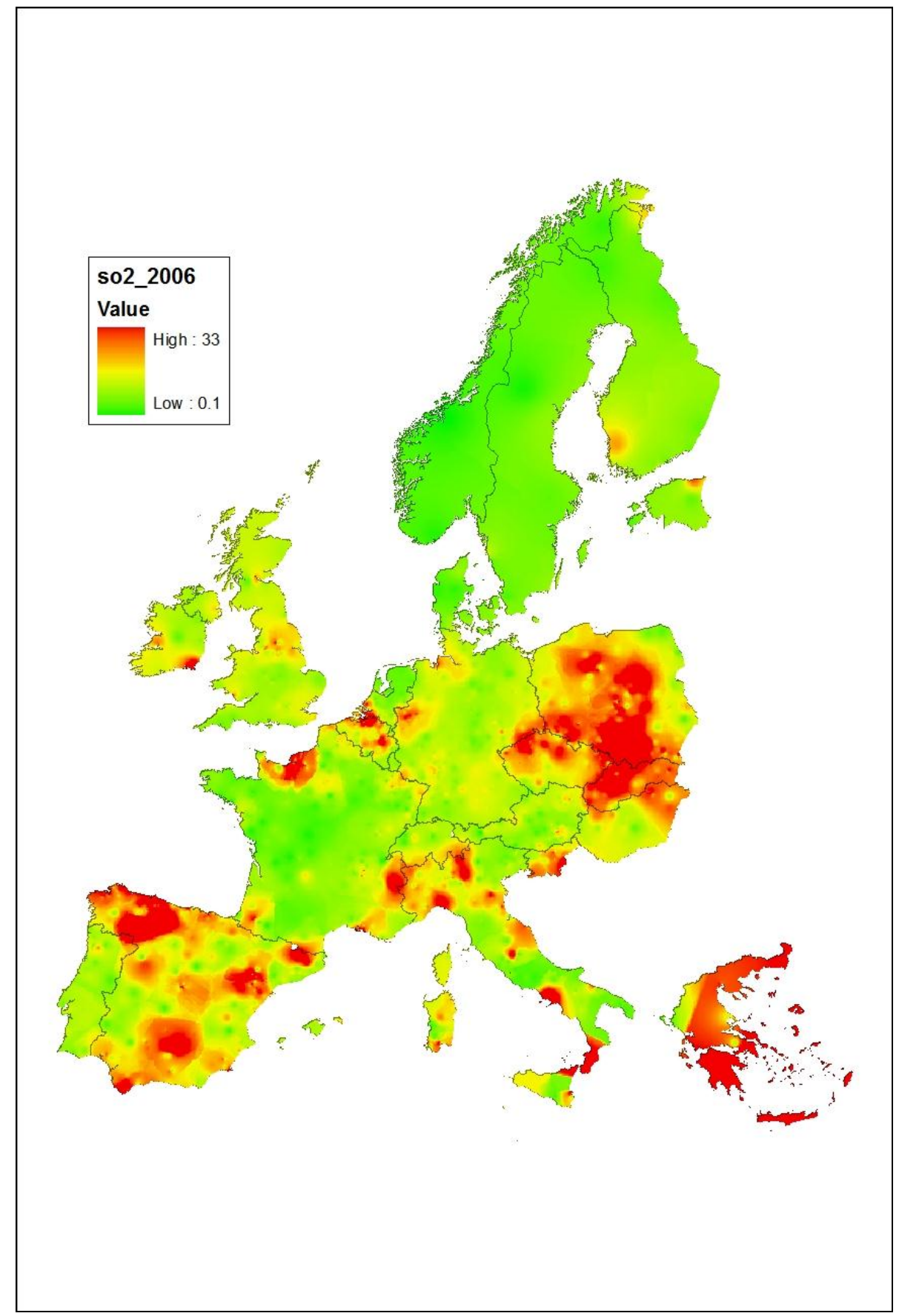

Figure 2: SO2 concentrations in Europe in 2006 